\section{Two New C-benzylated Dihydro- chalcone Derivatives from the Leaves of Melodorum siamensis}

\section{Uma Prawat, Orapan Chairerk, Unreuthai Phupornprasert, Abdul-Wahab Salae, Pittaya Tuntiwachwuttikul}

Laboratory of Natural Products Chemistry, Faculty of Science and Technology, Phuket Rajabhat University, Muang, Phuket, Thailand

\section{Abstract}

$\nabla$

Two new C-benzylated dihydrochalcone derivatives, 4,2',4'-trihydroxy-6'-methoxy-3'(2"-hydroxybenzyl)dihydrochalcone and 2',4'-dihydroxy-4,6'-dimethoxy-3'(2"-hydroxybenzyl)dihydrochalcone (2), along with six known flavonoid derivatives (38), a known dihydrochalcone dimer (9), three known aromatic esters (10-12), and one known aromatic amide (13), were isolated from the leaves of Melodorum siamensis. The structures of the compounds were elucidated by spectroscopic analysis, mainly $1 \mathrm{D}$ and 2D NMR techniques $\left({ }^{1} \mathrm{H},{ }^{13} \mathrm{C}, \mathrm{COSY}, \mathrm{HMQC}\right.$, and $\mathrm{HMBC}$ ), as well as by comparison with literature data. The isolated compounds with a sufficient amount for biological assays were evaluated for their antimalarial, antimycobactirial, and cytotoxic activities. Compounds 1, 2, and 13 exhibited strong cytotoxicity against human tumor cell lines KB and NCI-H187, with $\mathrm{IC}_{50}$ values in the range of $0.66-7.16 \mu \mathrm{g} / \mathrm{mL}$.

\section{Key words}

Melodorum siamensis · Annonaceae · antimycobacterial activity $\cdot$ antimalarial activity $\cdot$ cytotoxic activity

Supporting information available online at http://www.thieme-connect.de/ejournals/toc/plantamedica

The genus Melodorum (Annonaceae) comprises 55 species, which grow in tropical Asia [1]. Two species have been phytochemically investigated. The aporphine alkaloids were isolated from a mixed sample of M. punctulatum leaves and bark [2]. Several cytotoxic butenolides were isolated from the leaves of M. fructicosum [3, $4]$ and two oxidized heptanes were found in the flowers of the same plant [5]. In the course of our continuing search for bioactive constituents from Thai medicinal plants, a preliminary screening of the ethyl acetate extract of the leaves of Melodorum siamensis (Scheff.) Ban revealed cytotoxicity against human epimermoid carcinoma (KB), human breast cancer (MCF7), and human small cell lung cancer (NCI-H187) cell lines with IC $_{50}$ values of $1.7,2.4$, and $6.42 \mu \mathrm{g} / \mathrm{mL}$, respectively, antimalarial activity against Plasmodium falciparum with an $\mathrm{IC}_{50}$ value of $9.7 \mu \mathrm{g} / \mathrm{mL}$, and antimycobacterial activity against Mycobacterium tuberculosis H37Ra with an MIC value of $200 \mu \mathrm{g} / \mathrm{mL}$. Chemical and biological studies of this species have not been reported. This paper describes the isolation and structure elucidation of two new C-benzylated dihydrochalcone derivatives, 4,2',4'-trihydroxy-6'-methoxy-3'(2"-hydroxybenzyl)dihydrochalcone (1) and 2',4'-dihydroxy-4,6'-dimethoxy-3'(2"-hydroxybenzyl)dihydrochalcone (2), six known flavonoid derivatives, 4,2',4'-trihydroxy-6'-methoxydihydrochalcone (3), 2',4'-dihydroxy-4,6'-dimethoxydihydrochalcone (4), 2',4'-dihydroxy-4,6'-dimethoxychalcone (5), 2'- hydroxy-4,4',6'-trimethoxychalcone (6) [6], 7,4'-dihydroxy-5methoxyflavanone (7) [7,8], and 7-hydroxy-5,4'-dimethoxyflavanone (8) [6,9], a known dihydrochalcone dimer, 3',3"-bis2',4',6'-trihydroxy-4-methoxydihydrochalcone (9) [10], three known aromatic esters, benzyl benzoate (10), 2-methoxybenzyl benzoate (11) [11], and 3-phenylpropenyl 3-phenylallylate (12) [12], and a known aromatic amide, $p$-coumaroyl- $\beta$-phenethylamine (13) [13] from the leaves of M. siamensis ( $\bullet$ Fig. 1). Structure elucidation was performed using UV, IR, 1D and 2D NMR $\left({ }^{1} \mathrm{H},{ }^{13} \mathrm{C}, \mathrm{COSY}, \mathrm{HMQC}\right.$ and HMBC) and HR-TOF-MS spectroscopic techniques, as well as comparison with literature data. The biological activities of compounds 1-4, 7-11, and 13 are also reported. Compound 1 was obtained as a pale yellow solid and had the molecular formula $\mathrm{C}_{23} \mathrm{H}_{22} \mathrm{O}_{6}$ by HR-TOF-MS $\left(m / z\right.$ 395.1498 $[\mathrm{M}+\mathrm{H}]^{+}$, calcd. for $\left.\mathrm{C}_{23} \mathrm{H}_{23} \mathrm{O}_{6}, 395.1495\right)$. The UV spectrum showed absorption bands at $\lambda_{\max } 223,289$, and $334 \mathrm{~nm}$ and the IR spectrum indicated hydroxyl $\left(v_{\max } 3173 \mathrm{~cm}^{-1}\right)$, carbonyl $\left(v_{\max } 1631 \mathrm{~cm}^{-1}\right)$, and aromatic $\left(v_{\max } 1514 \mathrm{~cm}^{-1}\right)$ groups. The ${ }^{1} \mathrm{H}$ NMR spectrum of 1 showed two triplets at $\delta 2.86(J=7.7 \mathrm{~Hz})$ and $3.27(J=7.7 \mathrm{~Hz})$, which are typical of a dihydrochalcone moiety. This was consistent with the ${ }^{13} \mathrm{C}$ NMR data of 1 , which contained signals from two methylene carbons ( $\delta 30.8$ and 47.0) and a carbonyl carbon $\left(\delta\right.$ 205.8). The ${ }^{1} \mathrm{H}$ NMR spectrum of 1 also showed two doublets at $\delta 6.75(2 \mathrm{H}, J=8.3 \mathrm{~Hz})$ and $\delta 7.09(2 \mathrm{H}, J=8.3 \mathrm{~Hz})$ of a $p$-substituted aromatic ring (ring B) and a singlet at $\delta 6.14(1 \mathrm{H})$ at a pentasubstituted aromatic ring (ring $A$ ) of the dihydrochalcone. In addition, signals of one methoxy group at $\delta 3.86(3 \mathrm{H}, \mathrm{s})$, one hydrogen bonded phenolic hydroxyl group at $\delta 14.76(1 \mathrm{H}, \mathrm{s})$, and two phenolic hydroxyl groups were also observed in the ${ }^{1} \mathrm{H}$ NMR spectrum of $\mathbf{1}$. This was consistent with the ${ }^{13} \mathrm{C}$ NMR data of 1 which exhibited signals of one $p$-substituted aromatic ring (ring B) at $\delta$ 133.3 (C-1), 130.3 (C-2 and C-6), 116.1 (C-3 and C-5), and 156.6 (C-4), and one pentasubstituted aromatic ring (ring A) at $\delta 105.7$ (C-1'), 165.7 (C-2'), 107.8 (C-3'), 155.2 (C-4'), 91.9 (C-5'), and $162.8\left(\mathrm{C}-6^{\prime}\right)$. The ${ }^{1} \mathrm{H}$ NMR of 1 also indicated the presence of four adjacent aromatic protons at $\delta 6.83$ (dd, $\left.J=7.6,1.6 \mathrm{~Hz}, \mathrm{H}-3^{\prime \prime}\right), 7.00$ (td, $\left.J=7.6,1.6 \mathrm{~Hz}, \mathrm{H}-4^{\prime \prime}\right), 6.73$ (td, $\left.J=7.6,1.6 \mathrm{~Hz}, \mathrm{H}-5^{\prime \prime}\right)$, and 7.21 (dd, $J=7.6,1.6 \mathrm{~Hz}, \mathrm{H}-6^{\prime \prime}$ ), and a phenolic hydroxyl group and a singlet of two methylene protons at $\delta 3.89$, which were assigned to an 0 -hydroxybenzyl moiety [14]. This was consistent with the ${ }^{13} \mathrm{C}$ NMR spectrum, which exhibited signals of four aromatic methine carbons at $\delta 116.0$ (C-3"), 127.9 (C-4"), 120.7 (C-5"), and $131.2\left(\mathrm{C}-6^{\prime \prime}\right)$, one quaternary aromatic carbon at $\delta 127.9$ (C$\left.1^{\prime \prime}\right)$, one oxyquaternary aromatic carbon at $\delta 155.2\left(\mathrm{C}-2^{\prime \prime}\right)$, and one methylene carbon at $\delta 22.8$ (C-7"). The 2D HMBC data ( Fig. 2) revealed correlations between the proton signal of $6^{\prime}$ $\mathrm{OCH}_{3}(\delta 3.86)$ and $\mathrm{C}-6^{\prime}(\delta 162.8)$, between $2^{\prime}-\mathrm{OH}(\delta 14.76)$ and $\mathrm{C}-$ $2^{\prime}(\delta 165.7), \mathrm{C}-1^{\prime}(\delta 105.7)$ and $\mathrm{C}-3^{\prime}(\delta 107.8)$, and between $7 "-\mathrm{CH}_{2}$ $(\delta 3.89)$ and $C-3^{\prime}(\delta 107.8), C-2^{\prime}(\delta 165.7)$, and $C-4{ }^{\prime}(\delta 155.2)$. These results indicated that the methoxy group, the hydrogen bonded phenolic hydroxyl group, and the 0 -hydroxybenzyl moiety were attached to C-6', C-2', and C-3', respectively. Compound 1 was, therefore, assigned as 4,2',4'-trihydroxy-6'-methoxy-3'(2"'-hydroxybenzyl)dihydrochalcone.

Compound 2 was isolated as pale yellow crystals and had the molecular formula $\mathrm{C}_{24} \mathrm{H}_{24} \mathrm{O}_{6}$ by HR-TOF-MS $(\mathrm{m} / z \text { 409.1649 [M + H] }]^{+}$, calcd. for $\mathrm{C}_{24} \mathrm{H}_{25} \mathrm{O}_{6}, 409.1651$ ). The structure of 2 was closely related to 1 based on ${ }^{1} \mathrm{H}$ NMR, ${ }^{13} \mathrm{C}$ NMR ( $\bullet$ Table 1 ), IR, and UV spectroscopic data (Materials and Methods). However, $\mathbf{2}$ had one carbon and two hydrogen atoms more than 1 . The appearance of a three-proton singlet at $\delta 3.74$ and a methoxy carbon at $\delta 55.7$ in the ${ }^{1} \mathrm{H}$ and ${ }^{13} \mathrm{C}$ NMR spectra of 2 , respectively, suggested an addi- 
<smiles>[R]c1ccc(CCC(=O)c2c(OC)cc(O)c(Cc3ccccc3O)c2O)cc1</smiles><smiles>[R]c1ccc([C@@H]2CC(=O)c3c(OC)cc(O)cc3O2)cc1</smiles><smiles>COc1ccc(CCC(=O)c2c(O)cc(O)c(-c3c(O)cc(O)c(C(=O)CCc4ccc(OC)cc4)c3O)c2O)cc1</smiles><smiles>[R]c1ccccc1COC(=O)c1ccccc1</smiles>

$10 \mathrm{R}=\mathrm{H}$ $11 \mathrm{R}=\mathrm{OMe}$<smiles>O=C(/C=C/c1ccccc1)OC/C=C/c1ccccc1</smiles>

12<smiles>O=C(/C=C/c1ccc(O)cc1)NCCc1ccccc1</smiles>

13

Fig. 1 Structures of compounds 1-13.

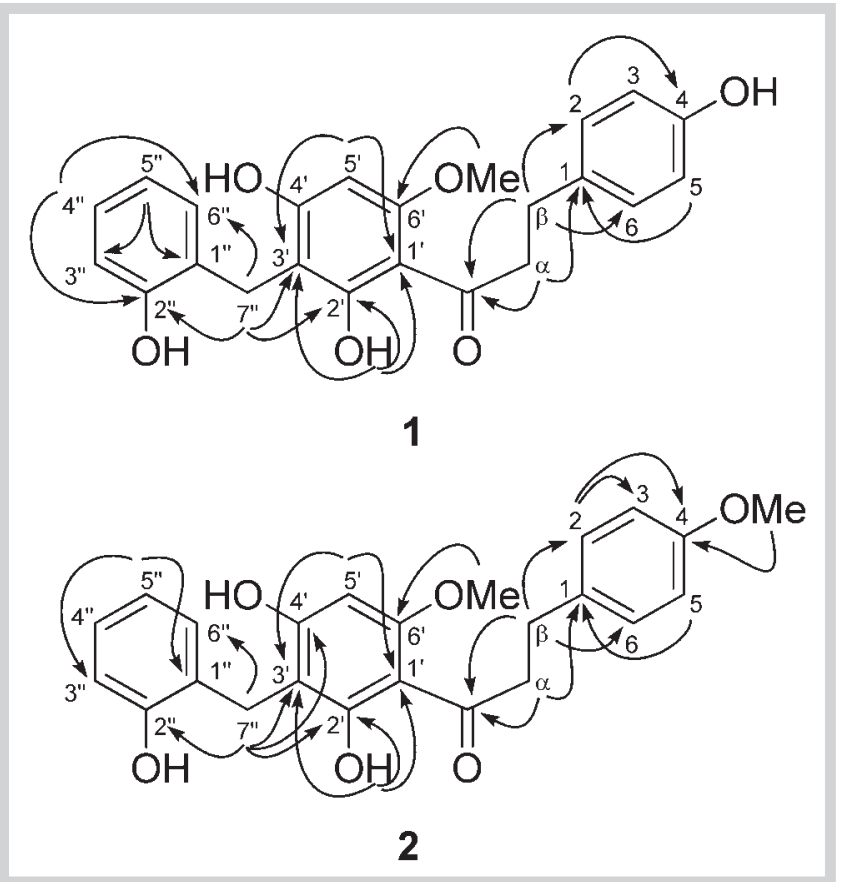

Fig. 2 Key HMBC correlations of compounds $\mathbf{1}$ and $\mathbf{2}$. tional methoxy group. The 2D HMBC correlations of the methoxy group, $4-\mathrm{OCH}_{3}(\delta 3.74)$ to $\mathrm{C}-4(\delta 159.2)$, and $\mathrm{H}-2$ and $\mathrm{H}-6(\delta$ 7.18) to C-3 ( $\delta 114.9), \mathrm{C}-5$ ( $\delta 114.9)$, and C-4 ( $\delta 159.2)$, confirmed the substitution of the methoxy group at C-4. Compound 2 was, therefore, deduced as 2',4'-dihydroxy-4,6'-dimethoxy-3'(2"-hydroxybenzyl)dihydrochalcone.

Most of the isolated compounds, except compounds 5, 6, and 12, which were isolated with insufficient amounts for the biological assay, were evaluated for their cytotoxicity against three human cancer cell lines [15] as summarized in 0 Table 2. Compounds 2 and 13 showed strong cytotoxicity in KB and NCI-H187 cell lines, with the $\mathrm{IC}_{50}$ in the range of $0.66-4.09 \mu \mathrm{g} / \mathrm{mL}$. Compound $1 \mathrm{ex}-$ hibited strong cytotoxicity in the NCI-H187 cell line with an $\mathrm{IC}_{50}$ value of $3.66 \mu \mathrm{g} / \mathrm{mL}$ and moderate activity in KB and MCF7 cell lines with $\mathrm{IC}_{50}$ values of 7.16 and $14.86 \mu \mathrm{g} / \mathrm{mL}$, respectively. The dihydrochalcones $\mathbf{3}$ and $\mathbf{4}$ showed moderate activity in all cell lines, with $\mathrm{IC}_{50} \mathrm{~S}$ in the range of $5.18-14.26 \mu \mathrm{g} / \mathrm{mL}$ while the flavanones $\mathbf{7}$ and $\mathbf{8}$ were less active. The dimeric dihydrochalcone $\mathbf{9}$ was inactive in all cell lines. Bioactivity results in 0 Table 2 showed that the presence of C-benzylated substituent on ring A of $\mathbf{1}$ and $\mathbf{2}$ appear to be an important moiety for cytotoxic activity, while the appearance of methoxy on ring B of $\mathbf{2}$ is essential for cytotoxicity against KB and NCI-H187 cells. The benzyl esters 10-11 were only moderately active in $\mathrm{KB}$ cell lines with $\mathrm{IC}_{50}$ values of 17.83 and $17.37 \mu \mathrm{g} / \mathrm{mL}$, respectively. Compounds 1-4, 711, and 13 were found to be inactive for antimalarial activity 


\begin{tabular}{|c|c|c|c|c|c|}
\hline \multirow[t]{2}{*}{ Position } & 1 & & 2 & & \multirow{28}{*}{$\begin{array}{l}\text { Table } 1 \text { NMR spectroscopic data } \\
\text { of } \mathbf{1} \text { and } \mathbf{2} \text { in acetone- } d_{6}(V \text { in } \mathrm{Hz} \text { in } \\
\text { parentheses). }\end{array}$} \\
\hline & $\delta_{\mathrm{H}}$ & $\delta_{c}$ & $\delta_{\mathrm{H}}$ & $\delta_{C}$ & \\
\hline 1 & & 133.3 & & 134.8 & \\
\hline 2 & $7.09 \mathrm{~d}(8.3)$ & 130.3 & $7.18 \mathrm{~d}(8.5)$ & 130.5 & \\
\hline 3 & $6.75 \mathrm{~d}(8.3)$ & 116.1 & $6.83 \mathrm{~d}(8.5)$ & 114.9 & \\
\hline 4 & & 156.6 & & 159.2 & \\
\hline 5 & $6.75 \mathrm{~d}(8.3)$ & 116.1 & $6.83 \mathrm{~d}(8.5)$ & 114.9 & \\
\hline 6 & $7.09 \mathrm{~d}(8.3)$ & 130.3 & $7.18 \mathrm{~d}(8.5)$ & 130.5 & \\
\hline $1^{\prime}$ & & 105.7 & & 106.0 & \\
\hline $2^{\prime}$ & & 165.7 & & 165.8 & \\
\hline $3^{\prime}$ & & 107.8 & & 108.1 & \\
\hline $4^{\prime}$ & & 155.2 & & 163.4 & \\
\hline $5^{\prime}$ & $6.14 \mathrm{~s}$ & 91.9 & $6.13 \mathrm{~s}$ & 92.1 & \\
\hline $6^{\prime}$ & & 162.8 & & 163.0 & \\
\hline$\alpha$ & $3.27 \mathrm{t}(7.7)$ & 47.0 & $3.28 \mathrm{t}(7.9)$ & 47.1 & \\
\hline$\beta$ & $2.86 \mathrm{t}(7.7)$ & 30.8 & $2.89 \mathrm{t}(7.9)$ & 30.9 & \\
\hline $\mathrm{CO}$ & & 205.8 & & 206.0 & \\
\hline $4-\mathrm{OCH}_{3}$ & & & $3.74 \mathrm{~s}$ & 55.7 & \\
\hline $2^{\prime}-\mathrm{OH}$ & $14.76 \mathrm{~s}$ & & $14.77 \mathrm{~s}$ & & \\
\hline \multicolumn{5}{|l|}{$4^{\prime}-\mathrm{OH}$} & \\
\hline $6^{\prime}-\mathrm{OCH}_{3}$ & $3.86 \mathrm{~s}$ & 56.2 & $3.84 \mathrm{~s}$ & 56.3 & \\
\hline $1^{\prime \prime}$ & & 127.9 & & 128.1 & \\
\hline $2^{\prime \prime}$ & & 155.2 & & 155.3 & \\
\hline $3^{\prime \prime}$ & $6.83 \mathrm{dd}(7.6,1.6)$ & 116.0 & $6.84 \mathrm{dd}(7.6,1.6)$ & 116.2 & \\
\hline $4^{\prime \prime}$ & $7.00 \operatorname{td}(7.6,1.6)$ & 127.9 & $7.01 \mathrm{td}(7.6,1.6)$ & 128.2 & \\
\hline $5^{\prime \prime}$ & $6.73 \mathrm{td}(7.6,1.6)$ & 120.7 & $6.74 \mathrm{td}(7.6,1.6)$ & 121.0 & \\
\hline $6^{\prime \prime}$ & $7.21 \mathrm{dd}(7.6,1.6)$ & 131.2 & $7.22 \mathrm{dd}(7.6,1.6)$ & 131.6 & \\
\hline $7^{\prime \prime}$ & $3.89 \mathrm{~s}$ & 22.8 & $3.89 \mathrm{~s}$ & 23.0 & \\
\hline
\end{tabular}

against the parasite Plasmodium falciparum $[16,17]$ and for antimycobacterial activity against Mycobacterium tuberculosis (H37Ra) [18].

\section{Materials and Methods \\ $\nabla$}

General: Melting points were determined on the Fisher-John melting point apparatus and the Buchi melting point B-540 apparatus, and are reported without correction. Optical rotations $[\alpha]_{D}$ were measured in $\mathrm{CHCl}_{3}$ solution at the sodium $\mathrm{D}$ line $(590 \mathrm{~nm})$ with a JASCO DIP-370 digital polarimeter. UV spectra were recorded with a Shimadzu UV-VIS 2001S spectrophotometer. IR spectra were recorded with a Perkin Elmer Spectrum One FT-IR spectrophotometer using the UATR technique. ${ }^{1} \mathrm{H}$ and ${ }^{13} \mathrm{C}$ NMR spectra were measured in $\mathrm{CDCl}_{3}$ and acetone- $d_{6}$ on a Bruker AVANCE 400 (400 MHz for ${ }^{1} \mathrm{H}$ NMR and $100 \mathrm{MHz}$ for ${ }^{13} \mathrm{C} \mathrm{NMR}$ ) spectrometer. Chemical shifts are given in $\delta(\mathrm{ppm})$ with tetramethylsilane as an internal standard. Coupling constants $(J)$ are given in $\mathrm{Hz}$. The signals in the ${ }^{1} \mathrm{H}$ and ${ }^{13} \mathrm{C}$ NMR spectra were assigned unambiguously using 2DNMR techniques: COSY, HMQC, and HMBC. EIMS were recorded on an MS Finnigan Polaris spectrometer. HRMS were recorded on a Bruker MicrOTOF mass spectrometer. HPLC was performed using a system comprised of Thermo Separation Product instruments (P4000 pump, UV6000LP for analysis, UV2000 for preparative). A reverse-phase column (SunFire Prep C8 $250 \times 21 \mathrm{~mm}, 10 \mathrm{~mm}$; Waters) was used for preparative HPLC. Column chromatography (CC) and vacuum liquid chromatography (VLC) were carried out on silica gel 60 (Scharlau, 230-400 mesh) and RP-18 and silica gel 60H (Scharlau, 200-300 mesh), respectively. TLC was performed on precoated silica gel $60 \mathrm{~F}_{254}$ plates (Merck); spots were detected by UV or spraying with $1 \% \mathrm{Ce}\left(\mathrm{SO}_{4}\right)_{2}$ in $10 \%$ aq. $\mathrm{H}_{2} \mathrm{SO}_{4}$ followed by heating. All commercial grade solvents were distilled prior to use and spectral grade solvents were used for spectroscopic measurements.
Plant material: The leaves of $M$. siamensis were collected in Songkhla Province, Thailand in 2007 and were identified by Dr. Piya Chalermglin, Thailand Institute of Scientific and Technological Research, Thailand. A voucher specimen (PKRU2007001) is deposited at the Laboratory of Natural Products Chemistry, Faculty of Science and Technology, Phuket Rajabhat University, Phuket, Thailand.

Extraction and isolation: The fresh leaves of M. siamensis (1.7 kg) were exhaustively extracted with EtOAc $(3 \times 8 \mathrm{~L})$ at room temperature, filtered, and concentrated to give a green crude extract (150 g). The EtOAc extract (145 g) was adsorbed onto $250 \mathrm{~g}$ of silica gel and fractionated by vacuum liquid chromatography (VLC) over a sintered glass filter column of silica gel to isolate pure compounds 1-13 (see Supporting Information).

4,2',4'-trihydroxy-6'-methoxy-3'(2"-hydroxybenzyl)dihydrochalcone (1): Pale yellow solid, mp $187-189^{\circ} \mathrm{C} ; \mathrm{UV}(\mathrm{MeOH}) \lambda_{\max }(\log$ $\varepsilon)$ : 223 (4.25), 289 (4.12), 334 (3.45) nm; IR (UATR-solid) $v_{\max }$ : 3173, 2925, 2853, 1631, 1514, 1441, 1365, 1306, 1214, 1196, 1107, 950, 800, $754 \mathrm{~cm}^{-1} ;{ }^{1} \mathrm{H}$ NMR and ${ }^{13} \mathrm{C}$ NMR (ه Table 1); HR-TOF-MS m/z: $395.1498[\mathrm{M}+\mathrm{H}]$ (calcd. for $\mathrm{C}_{22} \mathrm{H}_{23} \mathrm{O}_{6}$, 395.1495).

2',4'-dihydroxy-4,6'-dimethoxy-3'(2"-hydroxybenzyl)dihydrochalcone (2): Pale yellow crystals, mp 176-179 (dec.) ${ }^{\circ} \mathrm{C}$; UV (MeOH) $\lambda_{\max }(\log \varepsilon): 226$ (4.11), 292 (3.93), 336 (3.42) nm; IR (UATR-solid) $v_{\text {max }}: 3303,2933,2800,1612,1512,1454,1423,1296,1244$, 1196, 1138, 1105, 1036, 827, $756 \mathrm{~cm}^{-1} ;{ }^{1} \mathrm{H}$ NMR and ${ }^{13} \mathrm{C}$ NMR (ه Table 1); HR-TOF-MS m/z: $409.1649[\mathrm{M}+\mathrm{H}]^{+}$(calcd. for $\mathrm{C}_{24} \mathrm{H}_{25} \mathrm{O}_{6}$, 409.1651).

\section{Supporting information}

Detailed protocols for the extraction and isolation, in vitro cytotoxicity assay, in vitro antimalarial assay, and in vitro antibacterial assay, as well as 1D and 2D NMR spectra of compounds 1 and 2 are available as Supporting Information. 


\begin{tabular}{|llll|}
\hline Compounds $^{\mathbf{a}}$ & $\begin{array}{l}\mathbf{I C}_{\mathbf{5 0}} \boldsymbol{\mu \mathbf { g }} / \mathbf{m L} \\
\text { KB }\end{array}$ & MCF7 & \\
\hline $\mathbf{1}$ & 7.16 & 14.86 & NCI-H187 \\
\hline $\mathbf{2}$ & 2.02 & 20.03 & 3.66 \\
\hline $\mathbf{3}$ & 9.09 & 16.72 & 2.73 \\
\hline $\mathbf{4}$ & 5.18 & 10.92 & 14.26 \\
\hline $\mathbf{5}$ & $\mathrm{NT}$ & $\mathrm{NT}$ & $\mathbf{\text { NT }}$ \\
\hline $\mathbf{6}$ & $\mathrm{NT}$ & $\mathrm{NT}$ & $\mathrm{NT}$ \\
\hline $\mathbf{7}$ & 17.45 & $\mathrm{NA}$ & 16.97 \\
\hline $\mathbf{8}$ & 20.29 & $\mathrm{NA}$ & 17.74 \\
\hline $\mathbf{9}$ & $\mathrm{NA}$ & $\mathrm{NA}$ & $\mathrm{NA}$ \\
\hline $\mathbf{1 0}$ & 17.83 & $\mathrm{NA}$ & $\mathrm{NA}$ \\
\hline $\mathbf{1 1}$ & 17.37 & $\mathrm{NA}$ & $\mathrm{NA}$ \\
\hline $\mathbf{1 2}$ & $\mathrm{NT}$ & $\mathrm{NT}$ & $\mathrm{NT}$ \\
\hline $\mathbf{1 3}$ & 4.09 & $\mathrm{NA}$ & 0.66 \\
\hline Ellipticine $^{\mathrm{b}}$ & 0.224 & & 2.390 \\
\hline Doxorubicin $^{\mathrm{b}}$ & 0.176 & 1.290 & 0.029 \\
\hline
\end{tabular}

Table 2 Effects of 1-4, 7-11, and 13 against tumor cell lines replication.

a Purity (\%) of tested compounds were $>98 \%$. ${ }^{\mathrm{b}}$ This compound was used as a positive control ( $\left.95 \%\right)$; not active $(\mathrm{NA})=\mathrm{IC} 50>20 \mu \mathrm{g} / \mathrm{mL} ; \mathrm{not}$ tested (NT)

\section{Acknowledgements \\ $\nabla$}

We are indebted to the Office of the National Research Council of Thailand and Phuket Rajabhat University for financial support. The Bioassay Research Facility of BIOTEC/NASTDA Bangkok, Thailand is gratefully acknowledged for the bioactivity tests. We are grateful to Miss Kittiporn Trisupphakant and Mrs. Nitirat Chimnoi, Chulabhorn Research Institute, Bangkok, Thailand, for recording the UV, IR, MS, and HRMS spectra, and also to Miss Nareerat Thongtip, Phuket Rajabhat University, Phuket, Thailand, for recording the NMR spectra. We also thank Dr. Piya Chalermglin (Institute of Scientific and Technological Research, Thailand) for the identification of the plant.

\section{Conflict of Interest}

There are no conflicts of interest of all authors with respect to this work.

\section{References}

1 Chalermglin P. Annonaceaous plants. Bangkok: Amarin Printing and Publishing Public Co. Ltd.; 2001: 206

2 Bick IRC, Preston NW. Alkaloids of Melodorum punctulatum (Annonaceae). Aust J Chem 1971; 24: 2187-2188

3 Tuchinda P, Udchachon J, Reutrakul V, Santisuk T, Taylor WC, Farnsworth NR, Pezzuto JM, Kinghorn AD. Bioactive butenolides from Melodorum fruticosum. Phytochemistry 1991; 30: 2685-2689

4 Jung JH, Chang CJ, Smith DL, McLaughlin JL, Pummangura S, Chaichantipyuth C, Patarapanich C. Additional bioactive heptenes from Melodorum fruticosum. J Nat Prod 1991; 54: 500-505

5 Chaichantipyuth C, Tiyaworanan S, Mekaroonreung S, Ngamrojnavanich $N$, Roengsumran S, Puthong S, Petsom A, Ishikawa T. Oxidized heptenes from flowers of Melodorum fruticosum. Phytochemistry 2001; 58: $1311-1315$

6 Seidel V, Bailleul F, Waterman PG. (Rel)-1 $\beta, 2 \alpha$-di-(2, 4-dihydroxy-6-methoxybenzoyl)-3 $\beta, 4 \alpha$-di-(4-methoxyphenyl)-cyclobutane and other flavonoids from the aerial parts of Goniothalamus gardneri and Goniothalamus thwaitesii. Phytochemistry 2000; 55: 439-446

7 Hammami S, Ben JH, Bergaoui A, Ciavatta L, Cimino G, Mighri Z. Isolation and structure elucidation of a flavanone, a flavanone glycoside and vomifoliol from Echiochilon fruticosum growing in Tunisia. Molecules 2004; 9: 602-608

8 Singh VP, Yadav B, Pandey VB. Flavanone glycosides from Alhagi pseudalhagi. Phytochemistry 1999; 51: 587-590

9 Reiko T, Shunyo M, Tetsuro S. A new flavanone derivative from the leaves of Tsuga diversifolia. Planta Med 1989; 55: 570-571
10 Silva DHS, Yoshida M, Kato MJ. Flavonoids from Iryanthera sagotiana. Phytochemistry 1997; 46: 579-582

11 Kodpinid M, Sadavongvivad C, Thebtaranonth C, Thebtaranonth Y. Benzyl benzoates from the root of Uvaria purpurea. Phytochemistry 1984; 23: $199-200$

12 Hu LH, Zou HB, Gong JX, Li HB, Yang LX, Cheng W, Zhou CX, Bai H, Gueritte $F$, Zhao $Y$. Synthesis and biological evaluation of a natural ester sintenin and its synthetic analogues. J Nat Prod 2005; 68: 342-348

$13 \operatorname{Sinz}$ A, Matusch R, van Floris E, Santisuk T, Chaichana S, Reutrakul V. Phenolic compounds from Anomianthus dulcis. Phytochemistry 1999; 50: 1069-1072

14 Wirasathien L, Pengsuparp T, Moriyasu M, Kawanishi K, Suttisri R. Cytotoxic C-benzylated chalcone and other constituents of Ellipeiopsis cherrevensis. Arch Pharm Res 2006; 29: 497-502

15 Trager W, Jensen JB. Human malaria parasites in continuous culture. Science 1976; 193: 673-675

16 Collins LA, Franzblau SG. Microplate alamar blue assay versus BACTEC 460 system for high-throughput screening of compounds against $M y$ cobacterium tuberculosis and Mycobacterium avium. Antimicrob Agents Chemother 1997; 41: 1004-1009

17 Desjardins RE, Canfield CJ, Haynes JD, Chulay JD. Quantitative assessment of antimalarial activity in vitro by a semiautomated microdilution technique. Antimicrob Agents Chemother 1979; 16: 710-718

18 Skehan P, Storeng R, Scudiero D, Monks A, McMahon J, Vistica D, Warren JT, Bokesch H, Kenney S, Boyd MR. New colorimetric cytotoxicity assay for anticancer-drug screening. J Natl Cancer Inst 1990; 82: 1107-1112

received May 25, 2012

revised October 1,2012

accepted October 18, 2012

Bibliography

DOI http://dx.doi.org/10.1055/s-0032-1327950

Published online November 23, 2012

Planta Med 2013; 79: 83-86

(c) Georg Thieme Verlag KG Stuttgart - New York . ISSN 0032-0943

\section{Correspondence}

Assoc. Prof. Dr. Uma Prawat

Laboratory of Natural Products Chemistry

Faculty of Science and Technology

Phuket Rajabhat University

21 M.6 Thepkrasattree Road Radsada

Muang, Phuket 83000

Thailand

Phone: + 6676240474

Fax: + 6676211778

umaprawat@pkru.ac.th 